assisted instruction program, Library Explorer, is now available on the World Wide Web at http://www.lib.uiowa.edu/libexp/. Designed to engage UI students in independent, self-directed learning, Library Explorer on the Web helps people learn how to choose information sources, find appropriate tools, find books using the online catalog, and find periodicals using indexes. Library Explorer on the Web is hypertextual and can be perused like an electronic book; the program gives direct telnet access to the UI Libraries' online catalog. For more information on using Library Explorer, contact Marsha Forys at (319) 335-5301 or at marshaforys@uiowa.edu.

\section{ACRL's Instruction Section wants your comments on strategic plan}

ACRL's Instruction Section (IS) is developing a new strategic plan that will provide direction for the section's activities over the next several years. Like the recently adopted ACRL Strategic Plan on which it is modeled, the IS plan will be a dynamic document that will meet the changing needs of library instruction. At meetings held in New York City during the ALA Annual Conference last June, the section's executive committee and advisory council reviewed and approved a draft for general circulation among ACRL members.

The draft is available at http://www 2 . colgate.edu/instruction/. Please take time to review it and let the IS Advisory Council know what you think. There is still time to share your ideas on what you feel should be included in the new IS strategic plan and what direction IS should be taking over the next five years.

Send your suggestions (by e-mail if possible) to Karen Williams, Social Sciences Team, University of Arizona Library, Tucson, AZ 857210055; e-mail: kwilliam@bird.library.arizona.edu; phone: (520) 621-4865; fax: (520) 621-9733.

\section{OCLC introduces Bib Notification service}

OCLC has introduced Bib Notification, a service that automatically delivers upgraded, fulllevel OCLC-MARC records to libraries that have previously attached their symbol to less-thanfull bibliographic records. Bib Notification is available for all types of libraries.

"The University of Maryland at College Park Libraries is excited to be among the first to use OCLC's Bib Notification service," said John

\title{
ACRL seeks editor for book series, ACRL Publications in Librarianship
}

ACRL is seeking applicants for the editor of its book series, Publications in Librarianship (PIL), which began in 1952 and has produced a number of noteworthy works ranging from single-authored monographs to edited collections. These include Academic Libraries: Research Perspectives. edited by Mary Jo Lynch and Arthur Young (1990) and The Landscape of literatures, by Paul W. Metz (1983). The current editorial board is recruiting projects and the new editor will see some of these to publication as well as develop others.

Responsibilities: Together with a four- to seven-member editorial board, the editor is charged with encouraging research and writing that is appropriate for the series, identifying topics and authors for new books, refereeing submissions, and editing manuscripts for publication.

The new editor will serve on a volunteer basis and succeed Stephen E. Wiberley Jr., whose term ends in July 1998 . The incoming editor will first serve as associate editor from September 1997 until June 1998.

Requirements: ACRL membership is required. Candidates should have experience in research and writing, the ability to evaluate submissions and edit manuscripts, talent in working with authors, and an understanding of publishing.

How to apply: Persons wishing to be considered for the five-year term as editor should communicate their interest, accompanied by a statement of qualifications and names of three references by December 1 to: Ann C. Schaffner, Gerstenzang Science Library, Brandeis University, Waltham, MA 02254.

Adclitional information about the series is available from Stephen E. Wiberley Jr., UIC Library, Box 8198, m/c 234, Chicago, IL 606808198; phone: (312) 996-2730; fax: (312) 4130424; e-mail: wiberley@uic.edu. 